\title{
Study on process standardization and storage behaviour of pickle prepared from aonla (Emblica officinalis Gaertn.) cultivars
}

\begin{abstract}
Uttar Pradesh is the leading state in production and acreage under aonla cultivation in the country. Generally, aonla is considered as "Wonder Fruit for the Health" because aonla fruits are highly nutritious and having good medicinal value but fruits are not consumed freely in fresh form because of its astringent taste due to fruit tannins. The study aims to standardize the process of pickle preparation, which may become a popular method to prepare processed aonla product. Accordingly, eight aonla cultivars viz - Banarasi, Chakaiya, Kanchan, Krishna, NA - 6, NA - 7, NA - 8, NA - 9 were evaluated. Composition of aonla pickle with $1 \mathrm{~kg}$ aonla segments, $125 \mathrm{~g}$ salt, $10 \mathrm{~g}$ turmeric powder, $10 \mathrm{~g}$ red chillies powder, $25 \mathrm{~g}$ fenugreek, $10 \mathrm{~g}$ nigella seed, and $300 \mathrm{ml}$ mustard oil was found ideal for pickle preparation of NA- 7 aonla cultivars. Observations on vitamin ' $\mathrm{C}$ ' (ascorbic acid), total soluble solids (T.S.S.), acidity, and browning were recorded at the monthly interval. The periodical organoleptic assessment of pickle was also performed during storage. The result reported gradual reduction in the organoleptic scores of the aonla pickle, during storage. The acceptable quality of aonla pickle was found to be up to nine months. Therefore, NA-7 cultivar was found ideal for making pickle preparation.
\end{abstract}

Volume 5 Issue 3 - 202I

\author{
Rajendra Kumar \\ Assistant Professor (Sr. Grade), Amity Business School, Amity \\ University Uttar Pradesh, India
}

Correspondence: Rajendra Kumar, Assistant Professor (Sr. Grade), Amity Business School, Amity University Uttar Pradesh, Lucknow - 226028 (U.P.) India, Email vision.agri@rediffmail.com

Received: May 17, 202I | Published: June 03, 2021

Keywords: aonla, processed, products, preapartion, storage, quality, pickle

\section{Introduction}

The aonla (Indian gooseberry) is indigenous to Indian subcontinent. India ranks first in the world in area and production of aonla fruit crop. The aonla fruits, rich in pectin and minerals, can be used for making murrabba, pickles, etc. ${ }^{1}$ Large sized fruits, small seeds, high vitamin ' $\mathrm{C}$ ' and phenol contents and low fibre are some desirable traits for processing of aonla fruits particularly pickle preparation. The aonla varieties NA-6 and NA-9 have low contents of fibre and phenols with average composition of vitamin ' $\mathrm{C}$ ' and minerals. ${ }^{2}$ The aonla cultivar Chakaiya ${ }^{2}$ and NA $-9^{3}$ are the most suitable variety for making pickle. Deen ${ }^{4}$ reported that the pickle of Banarasi, Krishna, Kanchan, Chakaiya, NA-6, NA-7, NA-8, NA-9 and NA-10 showed acceptable quality than Francis and observed that pickle of NA-9 scored highest followed by NA- 6 and Banarasi.

Singh and $\mathrm{Kumar}^{3}$ prescribed that $1.0 \mathrm{Kg}$ aonla segments, $150 \mathrm{~g}$ salt, $10 \mathrm{~g}$ turmeric, $10 \mathrm{~g}$ red chillies powder, $30 \mathrm{~g}$ fenugreek, $10 \mathrm{~g}$ nigella seeds and $300 \mathrm{ml}$ mustard oil are better combination for aonla pickle. Almost similar recipe was reported by Srivastava and $\mathrm{Kumar}^{5}$ who reported that $1 \mathrm{~kg}$ aonla fruit, $150 \mathrm{~g}$ salt, $10 \mathrm{~g}$ turmeric powder, 10 $\mathrm{g}$ nigella seeds, $10 \mathrm{~g}$ chillies powder, $30 \mathrm{~g}$ fenugreek, 5 headless clove and $350 \mathrm{ml}$ mustard oil are added for preparation of aonla pickle. Mustard oil is reported to be effective in reducing the resistance of Bacillus subtilis sores. ${ }^{6,7}$

Brining is an important step in the process of making pickle. $10 \%$ sodium salt with addition of $0.3-0.5 \%$ acetic acid and about $0.5 \%$ turmeric powder in certain cases help to preserve the material in sound condition $^{8}$ It is reported that pickle prepared from aonla segments has slightly higher flavour and over all acceptability than whole fruit. ${ }^{9}$

The processing of fruit into pickle would be more nutritious other products available in the market and are being sold in large quantity in our country. In order to ensure the aonla production a profitable enterprise, there is dire need to explore the possibility of utilizing the aonla fruits for process products preparation because good quality processed aonla products can be prepared only from good quality of raw materials; hence cultivar selection is one of the important factors, which affect the quality of fruit products.

Keeping in view this fact, in present investigation an attempt has been made to evaluate pickle, prepared from fruits of different aonla cultivars.

\section{Material and methods}

The study was carried out at Department of Horticulture, Janta College, Bakewar, Etawah (U.P.). Matured, uniform sized and disease-free varieties of aonla fruits of eight cultivars viz. Banarasi, Chakaiya, Kanchan, Krishna, NA - 6, NA - 7, NA - 8, NA - 9 were selected and procured for pickle preparation from the experimental farm of Janta College, Bakewar, Etawah.

\section{Materials}

$1 \mathrm{~kg}$ aonla segments, $125 \mathrm{~g}$ salt, $10 \mathrm{~g}$ turmeric powder, $10 \mathrm{~g}$ red chillies powder, $25 \mathrm{~g}$ fenugreek, $10 \mathrm{~g}$ nigella seed, and $300 \mathrm{ml}$ mustard oil.

\section{Process of pickle preparation}

$1 \mathrm{~kg}$ aonla fruits thoroughly washed, were boiled in water for 10 minutes. The stones were then removed, and segments were kept for further processing. Other ingredients except salt were fried with oil and mixed with segments. The whole lot was again fried for 2 minutes. After mixing the salt, pickle was packed in sterilized, wide mouth bottles and kept in sunlight for 5 days and then stored for further studies. The process of pickle making is depicted in Flow chart 1. 


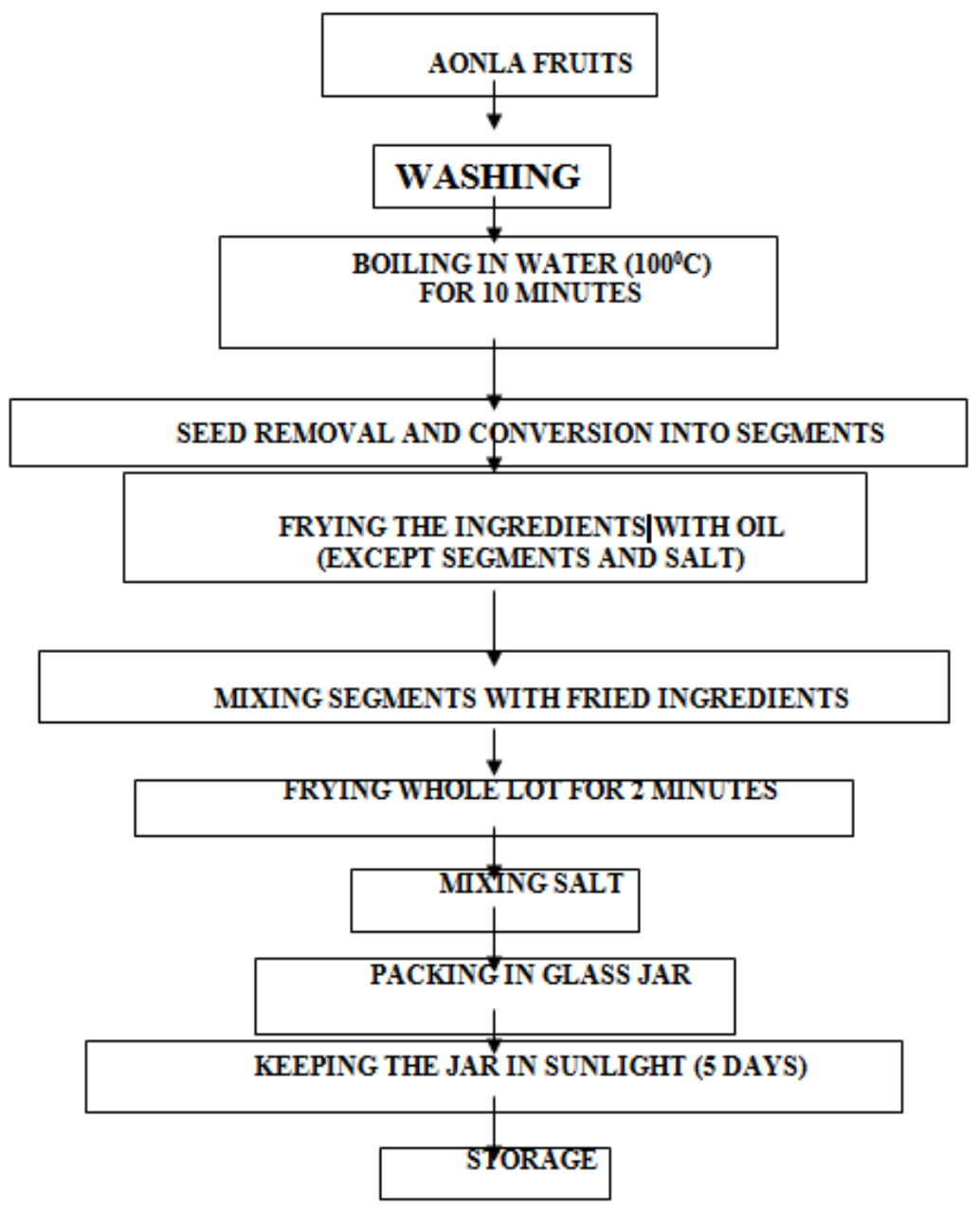

Flow chart I Technique used for preparation of aonla pickle.

\section{Organoleptic analysis}

Organoleptic quality of the pickle was evaluated by panel of 10 judges who scored on a 9-point Hedonic scale. ${ }^{10}$ The recipe which has been found ideal for pickle preparation was used for screening of cultivars. The prepared pickle was filled into jars. The jars were capped and kept in sunlight for 5 days and then stored at ambient temperature $\left(20 \pm 7^{\circ} \mathrm{C}\right)$ for storage studies. Observations on vitamin ' $\mathrm{C}$ ' (ascorbic acid), total soluble solids (T.S.S.), acidity, and browning were recorded at the monthly interval. The periodical organoleptic assessment of pickle was also performed during storage.

\section{Results}

\section{Evaluation of recipe}

The fruit segments of Banarasi, Chakaiya, Kanchan, Krishna, NA - 6, NA - 7, NA - 8, NA - 9 cultivars were used for pickle preparation. The recipe containing $1 \mathrm{~kg}$ fruit segments, $125 \mathrm{~g}$ salt, 10 $\mathrm{g}$ turmeric powder, $10 \mathrm{~g}$ red chillies powder, $25 \mathrm{~g}$ fenugreek, $10 \mathrm{~g}$ nigella seed, and $300 \mathrm{ml}$ mustard oil. Other ingredients except salt were fried with oil and mixed with segments. The whole lot was again fried for 2 minutes. After mixing the salt, pickle was packed in sterilized, wide mouth bottles and kept in sunlight for 5 days. Thereafter, The organoleptic quality of the product was assessed on the basis of color, appearance, texture and taste. The data given in Table 1 and their statistical analysis presented in Table 2, it is evident that the organoleptic rating of pickles prepared from various cultivars is varies from 7.0 to 9.0. The data also indicated that the rating of NA-7 was significantly higher as compared to other cultivars, it is recorded highest score (9.0) followed by NA-9 (8.1) and NA-6 (8.0). The difference in organoleptic score of pickle prepared from Banarasi (7.8), Chakaiya (7.0), Kanchan (7.2), Krishna (7.4), and NA-8 (7.4) cultivars was insignificant.

Table I Organoleptic quality of pickle prepared from aonla cultivars

\begin{tabular}{lll}
\hline \multirow{2}{*}{ Cultivars } & \multicolumn{2}{l}{ Organoleptic quality } \\
\cline { 2 - 3 } & Score & Rating \\
\hline Banarasi & 7.8 & Like moderately \\
Chakaiya & 7.0 & Like moderately \\
Kanchan & 7.2 & Like moderately \\
Krishna & 7.4 & Like moderately \\
NA-6 & 8.0 & Like very much \\
NA-7 & 9.0 & Like extremely \\
NA-8 & 7.4 & Like moderately \\
NA-9 & 8.1 & Like very much \\
C.D. at 5\% & 0.8 &
\end{tabular}


Table 2 Analysis of Variance of Pickle

\begin{tabular}{llll}
\hline Source of variance & d.f. & $\begin{array}{l}\text { Mean sum of } \\
\text { squares Pickle }\end{array}$ & $\begin{array}{l}\text { F } \\
\text { Calculated }\end{array}$ \\
\hline Replication & 6 & 0.18 & 0.332 \\
Treatment & 7 & 3.35 & 6.036 \\
Error & 42 & 0.56 & \\
\hline
\end{tabular}

\section{Qualitative changes during storage of aonla pickle}

The data presented in Table 3 revealed qualitative changes during storage of aonla pickle as follows:

\section{Vitamin 'C' (Ascorbic acid)}

During the preparation, vitamin $\mathrm{C}$ content was recorded at $68.10 \mathrm{mg}$ per $100 \mathrm{~g}$ of product, with $100 \%$ retention. This content decreased during the storage period. After nine months of storage this quantity was $26.50 \mathrm{mg}$ and it registered retention of $38.91 \%$.

Table 3 Qualitative changes during storage of pickle

\begin{tabular}{|c|c|c|c|c|c|c|c|c|c|c|}
\hline \multirow{3}{*}{$\begin{array}{l}\text { Storage } \\
\text { Period } \\
\text { (Month) }\end{array}$} & \multicolumn{10}{|c|}{ Qualitative changes during storage of pickle } \\
\hline & \multicolumn{2}{|l|}{ vitamin 'C’* } & \multicolumn{2}{|l|}{ TSS* } & \multicolumn{2}{|c|}{ Acidity $(\%) *$} & \multicolumn{2}{|c|}{ Browning* } & \multicolumn{2}{|c|}{ Organoleptic $* *$} \\
\hline & $\begin{array}{l}\text { Quantity } \\
\text { (mg/l00g) }\end{array}$ & Retention & $\begin{array}{l}\text { Quantity } \\
\text { (mg/l00g) }\end{array}$ & $\begin{array}{l}\text { Increase/ } \\
\text { Decrease } \\
(\%)\end{array}$ & $\begin{array}{l}\text { Quantity } \\
\text { (mg//00g) }\end{array}$ & $\begin{array}{l}\text { Increase/ } \\
\text { Decrease } \\
(\%)\end{array}$ & $\begin{array}{l}\text { Quantity } \\
\text { (OD) }\end{array}$ & $\begin{array}{l}\text { Increasel } \\
\text { Decrease } \\
(\%)\end{array}$ & Score & Rating \\
\hline 0 & 68.1 & 100 & 21 & 0 & 1.6 & 0 & I.I & 0 & 9 & LV \\
\hline I & 63.3 & 92.95 & 21 & 0 & 1.8 & 12.5 & 1.2 & 9.09 & 9 & LVM \\
\hline 2 & 58.7 & 86.2 & 21 & 0 & 2.2 & 37.5 & 1.2 & 9.09 & 8.8 & LVM \\
\hline 3 & 55.3 & 81.2 & 20.5 & -2.38 & 2.4 & 50 & 1.3 & 18.18 & 8.4 & LVM \\
\hline 4 & 51.1 & 75.04 & 20 & -4.76 & 1.8 & 12.5 & 1.3 & 18.18 & 8.4 & LVM \\
\hline 5 & 47.9 & 70.34 & 20 & -4.76 & 1.6 & 0 & 1.4 & 27.27 & 7.3 & LM \\
\hline 6 & 44.7 & 65.64 & 19.5 & -7.14 & 1.6 & 0 & 1.4 & 27.27 & 7.3 & LM \\
\hline 7 & 41.3 & 60.65 & 19 & -9.52 & 1.5 & -6.35 & 1.5 & 36.36 & 7.2 & LM \\
\hline 8 & 35.1 & 51.54 & 18.5 & -11.9 & 1.4 & -12.5 & 1.5 & 36.36 & 7.1 & LM \\
\hline 9 & 26.5 & 38.91 & 17.2 & -18.1 & 1.3 & -18.75 & 1.5 & 36.36 & 7 & LM \\
\hline
\end{tabular}

*Quantity expressed in mg/l00g; Retention expressed in \%

**Organoleptic score 7 and above acceptable

LE, like extremely; LVM, like very much; LM, like moderately; LS, like slightly

\section{Total soluble solids (T.S.S.)}

The pickle showed gradual decline in TSS content. At the time of preparation, pickle was having 21.00 TSS which gradually decreased to 17.2 . Thus, overall, $-18.10 \%$ decrement in TSS was recorded in pickle.

\section{Acidity}

During observation at the time of storages $1.60 \%$ acidity was seen which gradually decreased to $1.30 \%$. The acidity of pickle was also increased up to three months then it decreases continuously up to remaining period of storage.

\section{Browning}

Browning in terms of O.D. increased continuously during storage of pickle. The minimum browning was seen in the initial period of storage (1.10) and maximum (1.50) during the last three months of storage. Browning increased by $36.36 \%$ during the storage period.

\section{Organoleptic score}

Organoleptic score of aonla pickle decreased with the storage period and pickle were found acceptable up to nine months.

\section{Discussion}

Results also indicate that the vitamin " $C$ " content of pickle decreased continuously with the increasing storage period. The result corroborates with findings of Singh et al. ${ }^{2}$ who also recoded loss of ascorbic acid during storage of aonla. Reduction in vitamin ' $\mathrm{C}$ ' may be due to oxidation by trapped oxygen in container, which results in formation of dehydro ascorbic acid. Loss of ascorbic acid was also observed in aonla pickle. ${ }^{11}$

The total soluble solids (TSS) value in pickle started declining after two months of storage. The findings of Pathak ${ }^{11}$ support present findings the contention that total soluble solids increased up to two months after storage of aonla pickle and then started declining.

The acidity content in pickle increased up to three months and declined towards the end of storage. The findings corroborate with findings of Pathak; ${ }^{11}$ and Deen, ${ }^{4}$ who also noted similar trend acidity in aonla pickle.

A progressive increase in browning of pickle was observed with the storage period in present findings. This could be mainly due to the non-enzymatic reaction such as ascorbic acid with sugar or oxidation of phenols, which leads to the formation of brown pigments. The present findings get support with work on aonla pickle. ${ }^{11,4}$ 
Organoleptic score of the aonla pickle declined continuously during storage. The acceptable quality of aonla pickle was maintained up to acceptable upto nine months. Loss in organoleptic quality and storage stability of products after certain period is obvious. Temperature plays an important role in inducing certain biochemical changes in the products, which leads to development of off flavour as well as discoloration and thus masking the original colour and flavour of products. Reduction in organoleptic quality has also observed in aonla pickle. ${ }^{3}$ Similar reduction is also observed in aonla pickle. ${ }^{11,4}$

\section{Conclusion}

The study showed that composition of aonla pickle with $1 \mathrm{~kg}$ aonla segments, $125 \mathrm{~g}$ salt, $10 \mathrm{~g}$ turmeric powder, $10 \mathrm{~g}$ red chillies powder, $25 \mathrm{~g}$ fenugreek, $10 \mathrm{~g}$ nigella seed, and $300 \mathrm{ml}$ mustard oil was found ideal for pickle preparation of $\mathrm{N} 7$ aonla cultivar. On the basis of observation recorded during the storage of pickle, it is indicating that vitamin " $C$ " decreased, TSS first increased then decreased. Acidity also declined gradually. Browning of aonla pickle increased continuously during storage. Oraganoleptic score of the aonla pickle also reduced gradually during storage. The acceptable quality of aonla pickle was up to nine months. Overall, changes and reduction of quality were found in aonla pickle during storage. The NA-7 cultivar was found ideal for making pickle preparation.

\section{Funding}

None.

\section{Acknowledgments}

None.

\section{Conflicts of interest}

The authors have no conflict of interest for this research.

\section{References}

1. A Harshvardhan, Chikkasubbanna V. Quality and organoleptic evaluation of amla pickle. The Asian Journal of Horticulture. 2010;4(2):271-274.

2. Singh IS, Pathak RK, Dwivedi R, et al. Aonla production and post-harvest technology. Tech. Bulletin, Narendra Dev University of Agriculture and Technology, Kumarganj, Faizabad (U. P.).

3. Singh IS, Kumar S. Studies on processing of aonla fruits- II. Aonla products. Prg Hort. 1995;27(1-2):39-47.

4. Deen B. Studies on screening of aonla (Emblica officinalis Gaertn) genotypes for processing. M. Sc. Thesis. Narendra Dev University of Agriculture and Technology, Kumarganj, Faijabad. 1992.

5. Srivastava RP, Kumar S. Fruit and vegetable preservation principles and practices. II ed. International Book Distributing Co., Lucknow. 2002.

6. Bose AN, Roy AK. Studies on heat resistance of Bacillus subtilis spores II. Effect of different spices, J Sci and Indus Res. 1960;19: 277.

7. Yadav A, Singh U, Yadav A. Aonla, physico-chemical and microbial quality during storage. International Research of Chemistry. 2017;18(2):14-21.

8. Anand JC, Johar DS. Note on the micro-biology brined mango slices. Indian J. Hort. 1951;8:45.

9. Premi BR, Sethi V, Bisaria G. Preparation of instant oil less pickle from aonla (Emblica officinalis Gaertn). Ind Fd Pack. 2002;56(3):72.

10. Amerine, MA, Pangborn RM, Roessler EB. Principle of sensory evaluation of food. Academic press, New York and London. 1965.

11. Pathak S. Post-harvest technology of aonla (Emblica officinalis Gaertn) fruits. Ph. D. Thesis, Narendra Dev University of Agriculture and Technology, Faizabad (U. P.). 1988. 